\title{
Pengaruh kadar hemoglobin terhadap lebam mayat (livor mortis)
}

\author{
${ }^{1}$ Reynaldo B. Umboh \\ ${ }^{2}$ Nola T. S. Mallo \\ ${ }^{2}$ Erwin G. Kristanto
}

\author{
${ }^{1}$ Kandidat Skripsi Fakultas Kedokteran Universitas Sam Ratulangi Manado \\ ${ }^{2}$ Bagian Ilmu Kedokteran Forensik Medikolegal Universitas Sam Ratulangi Manado \\ Email: reynaldobryan12055@gmail.com
}

\begin{abstract}
Abstact: Death can be identified by using advanced signs of death as follows: postmortem lividity (livor mortis), rigor mortis, decomposition, mummification, and adipocere. Postmortem lividity occurs right after clinical signs of death. Erythrocytes will accumulate to the lowest area of the body due to gravity, fill the veins and venules, and then form reddish purple spots called lividity. This study aimed to find the effect of hemoglobin level on colors indicating postmortem lividity and the time when the lividity vanishes due to pressure. This study used a cross-sectional design and was carried out at Prof. Dr. R. D. Kandou Hospital Manado from October to December 2015. In this study, pressure was given to the livor mortis of the deceased patients. Hemoglobin levels were obtained from the medical records. The results showed that there was a statistically significant effect of hemoglobin levels on the vanishing time of livor mortis ( $\mathrm{p}<0.05, \mathrm{p}=0.040)$, meanwhile there was no significant effect of hemoglobin levels on the colors indicating livor mortis (constant). Additional samples with more accurate instrument for measuring the differences in colors and periodical documentation with videos are recommended for further studies.
\end{abstract}

Keywords: hemoglobin postmortem lividity (livor mortis)

\begin{abstract}
Abstrak: Kematian dapat dikenal pada seseorang melalui adanya tanda-tanda kematian lanjut berupa lebam mayat, kaku mayat, pembusukan, mumifikasi dan adiposera. Lebam mayat (livor mortis) terjadi setelah kematian klinis. Eritrosit akan menempati tempat terbawah akibat gaya gravitasi, mengisi vena dan venula, membentuk bercak warna merah ungu (livide) pada bagian terbawah tubuh. Penelitian ini bertujuan untuk melihat pengaruh kadar hemoglobin terhadap warna lebam mayat dan hilangnya (detik) ketika diberi penekanan. Jenis penelitian potong lintang. Penelitian dilakukan di RSUP Prof. Dr. R. D. Kandou Manado pada bulan Oktober - Desember 2015 dengan mengamati dan menekan lebam mayat pasien meninggal. Data rekam medis pasien ditelusuri untuk melihat kadar hemoglobin. Hasil penelitian menunjukkan terdapat pengaruh kadar hemoglobin terhadap hilangnya lebam mayat pada penekanan $(p<0,05$ atau $p=0,040)$ dan tidak ada pengaruh kadar hemoglobin terhadap warna lebam mayat (livor mortis) $=$ konstan. Disarankan untuk penelitian selanjutnya agar menggunakan sampel yang lebih banyak dengan penggunaan alat ukur warna maupun alat ukur untuk melakukan penekanan serta melakukan dokumentasi foto ataupun video secara berkala.
\end{abstract}

Kata kunci: hemoglobin, lebam mayat (livor mortis)

Kematian dapat dikenal secara klinis pada seseorang berupa tanda kematian, yaitu perubahan yang terjadi pada tubuh mayat. Perubahan tersebut dapat timbul dini pada saat meninggal atau beberapa menit kemudian, misalnya kerja jantung dan peredaran darah berhenti, pernapasan berhenti, refleks cahaya dan refleks kornea 
mata hilang, kulit pucat dan relaksasi otot. Setelah beberapa waktu timbul perubahan pasca mati yang jelas yang memungkinkan diagnosis kematian lebih pasti. Tanda-tanda tersebut dikenal sebagai tanda kematian lanjut berupa lebam mayat (hipostatis atau livididat pasca-mati), kaku mayat (rigor mortis), pembusukan, mumifikasi dan

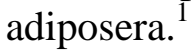

Lebam mayat (livor mortis) terjadi setelah kematian klinis. Eritrosit akan menempati tempat terbawah akibat gaya tarik bumi (gravitasi), mengisi vena dan venula, membentuk bercak warna merah ungu (livide) pada bagian terbawah tubuh, kecuali pada bagian tubuh yang tertekan alas keras. ${ }^{1}$ Faktor yang memengaruhi lebam mayat diantaranya kadar $\mathrm{Hb}$ dan/atau banyaknya volume darah yang beredar. ${ }^{2,3}$

Hemoglobin merupakan molekul protein besar berisi besi yang ditemukan di dalam eritrosit dan berikatan serta mengangkut sebagian besar $\mathrm{O}_{2}$ dalam darah; juga mengangkut sebagian $\mathrm{CO}_{2}$ dan $\mathrm{H}^{+}$dalam darah. ${ }^{4}$ Hemoglobin memiliki afinitas (daya gabung) terhadap oksigen dan dengan oksigen itu membentuk oksihemoglobin di dalam sel darah merah. Dengan melalui fungsi ini maka oksigen dibawa dari paru-paru ke jaringanjaringan,berada di dalam eritrosit dan bertugas untuk mengangkut oksigen. Kualitas darah ditentukan oleh kadar hemoglobin. ${ }^{5,6}$

Anemia merupakan masalah kesehatan yang berkaitan dengan hemoglobin. Menurut Riset Kesehatan Dasar 2013, Secara nasional, proporsi anemia penduduk $\geq 1$ tahun di Indonesia sebesar 21,7\%; pada balita $12-59$ bulan 28,1\%, dan ibu hamil sebesar 37,1\%. ${ }^{7}$ Masalah ini juga dapat mengakibatkan masalah kematian maternal.

Lebam mayat akan mulai tampak sekitar 30 menit setelah kematian klinis dan intensitas maksimal akan dicapai dalam waktu 8-12 jam post-mortem. Dengan demikian penekanan pada daerah lebam mayat atau perubahan posisi mayat yang dilakukan 8-12 jam tersebut lebam mayat tidak akan menghilang. Tidak menghilangnya lebam mayat pada saat itu dikarenakan telah terjadi perembesan darah akibat rusaknya pembuluh darah ke dalam jaringan sekitar pembuluh darah. ${ }^{4}$

Kegunaan untuk melihat lebam mayat yaitu lebam mayat merupakan tanda pasti kematian oleh karena hanya dapat terjadi setelah mati somatis/klinis; memperkirakan posisi/sikap mayat sebelum dilakukan perubahan, bila lebam mayat telah terbentuk pada saat perubahan posisi dilakukan tetapi bila perubahan dilakukan sebelum lebam mayat terbentuk, posisi/sikap mayat awal tidak dapat ditentukan; memperkirakan saat kematian; memperkirakan sebab kematian dari warna lebamnya. Pada umumnya lebam mayat berwarna merah-ungu (livide), akan tetapi pada beberapa keadaan tertentu akan menjadi lain. Dengan demikian adanya warna lebam mayat yang berbeda akan dapat memberikan informasi bahwa pada korban telah terjadu sesuatu yang berkaitan dengan penyebab kematian ataupun lingkungan dimana tubuh korban ditemukan. Terdapat lima warna lebam mayat yang dapat memperkirakan penyebab kematian yaitu: warna merah kebiruan/merah keunguan merupakan warna normal lebam; warna merah terang menandakan keracunan CO, keracunan CN atau suhu dingin; warna merah gelap menunjukkan asfiksia, warna biru menunjukkan keracunan nitrit, warna coklat menunjukkan keracunan aniline. , 3,8,9

Faktor-faktor yang memengaruhi lebam mayat yaitu volume darah yang beredar; lamanya darah dalam keadaan cepat cair; warna lebam. Pada anemia berat lebam mayat yang terjadi sedikit, warna lebih muda dan terjadinya lebih lambat. Pada polisitemia sebaliknya lebam mayat lebih cepat terjadi. ${ }^{3}$

Pada tahap awal pembentukannya lebam mayat (livor mortis) memiliki warna kemerahan yang dihasilkan dari jumlah eritrosit yang membawa hemoglobin yang teroksidasi. Meningkatnya interval postmortem akan mengakibatkan perubahan warna menjadi lebih gelap. Warna normal 
livideakan berubah menjadi warna lebih ungu akibat hasil pemisahan oksigen dari hemoglobin eritrosit post-mortem dan konsumsi oksigen terus-menerus oleh selsel yang awalnya mempertahankan fungsi kardiovaskuler sehingga akan menghasilkan produk deoksihemoglobin yang akan mengubah warna livide menjadi warna ungu. $^{10}$

Penelitian ini bertujuan untuk mengetahui pengaruh kadar hemoglobin terhadap lebam mayat (livor mortis). Tujuan khususnya yaitu untuk mengetahui pengaruh kadar hemoglobin terhadap hilangnya (detik) lebam mayat pada penekanan dan pengaruh kadar hemoglobin terhadap warna lebam mayat.

\section{METODE PENELITIAN}

Penelitian ini menggunakan desain potong lintang. Penelitian ini dilakukan di RSUP Prof. Dr. R. D. Kandou Manado pada bulan Oktober-Desember 2015. Banyaknya sampel dihitung menggunakan rumus Slovin.

Penelitian dilakukan dengan mengamati dan menekan lebam mayat pasien meninggal yang masuk bagian Forensik Medikolegal RSUP Prof. Dr. R. D. Kandou Manado yang sebelumnya dirawat di RSUP Prof. Dr. R. D. Kandou Manado pada saat sebelum dilakukan tindakan pengawetan (formalin). Data rekam medis pasien meninggal ditelusuri untuk melihat kadar hemoglobin.

Data yang diperoleh diolah menggunakan aplikasi SPSS dan disajikan dalam bentuk tabel.

\section{HASIL PENELITIAN}

Berdasarkan rumus Slovin didapati 42 sampel pasien meninggal yang masuk bagian Forensik Medikolegal RSUP Prof. Dr. R. D. Kandou.

\section{Hasil univariat}

Pada Tabel 1 terlihat bahwa laki-laki lebih banyak dari pada perempuan.

Pada Tabel 2 terlihat bahwa usia $>50$ tahun jauh lebih banyak.

Pada Tabel 3 terlihat bahwa warna kulit sawo matang lebih banyak

Tabel 1. Distribusi sampel menurut jenis kelamin

\begin{tabular}{ccc} 
Jenis kelamin & Frekuensi & $\%$ \\
\hline L & 27 & 64,3 \\
P & 15 & 35,7 \\
Total & 42 & 100,0 \\
\hline
\end{tabular}

Tabel 2. Distribusi sampel menurut usia

\begin{tabular}{ccc} 
Usia & Frekuensi & $\%$ \\
\hline$<25$ thn & 8 & 19,0 \\
\hline $25-50$ thn & 8 & 19,0 \\
\hline$>50$ thn & 26 & 61,9 \\
\hline Total & 42 & 100,0 \\
\hline
\end{tabular}

Tabel 3. Distribusi sampel menurut warna kulit

\begin{tabular}{ccc} 
Warna kulit & Frekuensi & $\%$ \\
\hline Coklat & 3 & 7,1 \\
Kuning langsat & 14 & 33,3 \\
Sawo matang & 25 & 59,5 \\
Total & 42 & 100,0 \\
\hline
\end{tabular}

Pada Tabel 4, terlihat bahwa kadar hemoglobin kurang dari 10 lebih banyak.

Tabel 4. Distribusi sampel menurut kadar hemoglobin $(\mathrm{Hb})$

\begin{tabular}{ccc}
$\begin{array}{c}\text { Hemoglobin } \\
(\mathrm{gr} / \mathrm{dl})\end{array}$ & Frekuensi & $\%$ \\
\hline$<10$ & 23 & 54,8 \\
$10-17$ & 18 & 42,9 \\
$>17$ & 1 & 2,4 \\
Total & 42 & 100,0 \\
\hline
\end{tabular}

Pada Tabel 5 terlihat bahwa semua sampel memiliki warna lebam mayat livide

Tabel 5. Distribusi sampel menurut warna lebam mayat

\begin{tabular}{lcc} 
Warna & Frekuensi & $\%$ \\
\hline livide & 42 & 100,0 \\
\hline
\end{tabular}

Pada Tabel 6 terlihat bahwa lebam mayat lebih banyak hilang dalam 4 detik setelah diberi penekanan lalu muncul lagi. Pada Tabel 7 terlihat bahwa lebih 
banyak sampel yang didiagnosis akhir dengan syok sepsis.

Tabel 6. Distribusi sampel menurut waktu (detik) hilang lebam saat penekanan

\begin{tabular}{ccc}
$\begin{array}{c}\text { Waktu hilang } \\
\text { (detik) }\end{array}$ & Frekuensi & $\%$ \\
\hline 2 & 4 & 9,5 \\
3 & 9 & 21,4 \\
4 & 11 & 26,2 \\
5 & 7 & 16,7 \\
6 & 7 & 16,7 \\
7 & 2 & 4,8 \\
8 & 2 & 4,8 \\
Total & 42 & 100,0 \\
\hline
\end{tabular}

Tabel 7. Distribusi sampel menurut diagnosis akhir

\begin{tabular}{lcc}
\multicolumn{1}{c}{ Diagnosis akhir } & Frekuensi & $\%$ \\
\hline Cardiac arrest & 3 & 7,1 \\
$\quad$ Ensefalopati & 2 & 4,8 \\
$\quad$ Uremika & 9 & 21,4 \\
$\quad$ Gagal Napas & 1 & 2,4 \\
$\quad$ Herniasi & 1 & 2,4 \\
$\quad$ Leukemia & 4 & 9,5 \\
MOF & 1 & 2,4 \\
Perdarahan & 1 & 2,4 \\
Intrakran & 19 & 45,2 \\
Sepsis & 1 & 2,4 \\
Syok Sepsis & 42 & 100,0 \\
Trauma Cervical &
\end{tabular}

\section{Hasil bivariat}

Pada Tabel 8 terlihat pengaruh kadar hemoglobin terhadap hilang lebam mayat pada penekanan (detik).

Hasil penilaian kadar hemoglobin terhadap warna lebam mayat secara makroskopis menunjukkan warna yang sama pada setiap sampel yaitu livide yang dalam hal ini konstan.

Tabel 8. Kadar hemoglobin terhadap hilang lebam mayat pada penekanan (detik)

\begin{tabular}{cccc}
$\mathrm{R}$ & R Square & $\mathrm{F}$ & Sig. \\
\hline, $318^{\mathrm{a}}$ &, 101 & 4,488 &, $040^{\mathrm{b}}$ \\
\hline
\end{tabular}

\section{BAHASAN}

Secara statistik terdapat pengaruh kadar hemoglobin terhadap hilangnya lebam mayat (livor mortis) pada penekanan (detik) (Tabel 8) $(p<0,05$ atau $p=0,04)$ dengan $\mathrm{R}$ square sebesar 0,101 yang berarti pengaruh hilangnya lebam mayat (livor mortis) ketika ditekan terhadap kadar hemoglobin $(\mathrm{Hb})$ sebesar 10,1\%, sedangkan sisanya dipengaruhi oleh variabel yang lain.

Secara teori lebam mayat (livor mortis) akan hilang atau menetap setelah 8-12 jam. ${ }^{3}$ Waktu merupakan penentu hilang tidaknya lebam yang muncul. Tidak menghilangnya lebam mayat (livor mortis) pada saat itu dikarenakan telah terjadi perembesan darah akibat rusaknya pembuluh darah ke dalam jaringan sekitar pembuluh darah. Pada penelitian ini sampel yang diamati tidak lebih dari 3 jam postmortem sehingga pada penekanan lebam masih hilang dengan variasi waktu (detik) dan kadar hemoglobin yang berbeda.

Pada penelitian ini didapatkan bahwa dari 42 sampel penelitian pasien meninggal tidak ditemukan adanya variasi warna lebam yang muncul (konstan) (Tabel 5). Scara statistik tidak ada pengaruh antara kadar hemoglobin terhadap warna lebam mayat (livor mortis) yang muncul. Secara makroskopik didapati warna lebam yang sama atau warna lebam pada umumnya (livide). $^{2}$ Secara teori meningkatnya interval post-mortem akan mengakibatkan perubahan warna menjadi gelap dimana terjadi pemisahan oksigen dari hemoglobin eritrosit post-mortem. ${ }^{10} \mathrm{Hal}$ ini mungkin disebabkan oleh karena hanya dilakukan pengamatan kasat mata saja dengan tidak menggunakan alat pengukur atau indikator warna dan juga karena pasien yang meninggal tidak didapati adanya riwayat keracunan. Pasien meninggal dengan keracunan akan memberikan warna lebam yang berbeda sesuai dengan zat atau keadaan sekitar tubuh pasien. ${ }^{3,11}$ Bila saat pengukuran dibantu dengan alat ukur atau indikator warna kemungkinan akan mendapatkan hasil yang bervariasi.

\section{SIMPULAN}

Berdasarkan hasil penelitian dan bahasan dapat disimpulkan bahwa: 
1. Terdapat pengaruh kadar hemoglobin (Hb) terhadap hilangnya lebam mayat (livor mortis) pada penekanan sebesar $10,1 \%$.

2. Tidak ada pengaruh kadar hemoglobin (Hb) terhadap warna lebam mayat (livor mortis) $=$ konstan .

\section{SARAN}

Disarankan untuk penelitian selanjutnya untuk menambah jumlah sampel penelitian sehingga hasil penelitian menjadi lebih heterogen dan representatif. Sebaiknya proses dokumentasi dilakukan dengan menggunakan foto dengan resolusi tinggi agar kualitas gambar lebih baik dan atau menggunakan video untuk melihat lebam yang hilang pada penekanan.

Untuk penelitian selanjutnya sebaiknya menggunakan alat ukur untuk menekan lebam mayat agar penekanan yang diberikan selama penelitian sama atau konstan dan alat ukur warna untuk menilai warna lebam.

\section{DAFTAR PUSTAKA}

1. Budiyanto A, Widiatmaka W, Sudiono S, Mun'im TWA, Hertian S, Sampurna B, et al. Jakarta: Fakultas Kedokteran Universita Indonesia,
1997; p. 25-6.

2. Mason JK. Forensic Medicine for Lawyers (2nd ed). ELBS, 1983.

3. Idries AM. Pedoman Ilmu Kedokteran Forensik (1st ed). Jakarta: Binarupa Aksara, 1997.

4. Sherwood L. Fisiologi Manusia (6th ed). Jakarta: EGC, 2009; p. 423-8.

5. Evelyn. Anatomi dan Fisiologi untuk Paramedis. Jakarta: Gramedia Pustaka Utama, 2000

6. Guyton A, Hall JE. Buku Ajar Fisiologi Kedokteran (9th ed). Jakarta: EGC, 1996.

7. Riset Kesehatan Dasar 2013.

8. Budi S, Zulhasmar S, Tjetjep DS. Peranan Ilmu Forensik dalam Penegakan Hukum. Jakarta, Pustaka Dwipar, 2008; p. 185-7.

9. Spitz WU. Drowning. In: Medicolegal Investigation of Death "Guidelines for the Application ofPathology to Crime Investigation". Charles C. Thomas. 1997. USA: 294-309

10.Tsokos M. Forensic Pathology Reviews Volume 3. New Jersey: Humana Press, 2005; p. 191.

11.Dix J, Graham M. Time of Death, Decomposition and Identification An Atlas. New York: CRC Press LLC, 2000; p. 10-27. 